\title{
Correlating Socio-Economic Attributes With Users' Residential Satisfaction: Implications For Housing Policy In Ibadan Metropolis, Nigeria
}

\author{
Babatunde Femi Akinyode \\ Department of Urban and Regional Planning \\ Faculty of Environmental Sciences, Ladoke Akintola University of Technology
}

\begin{abstract}
This study investigated the influence of socio-economic attributes on users' affordable housing satisfaction. Obviously, it identified how users' socio-economic attributes significantly impact on users' satisfaction on their affordable housing and the choice of the environment. This is with a view of having better understanding of how housing policy making can integrate socio-economic attributes to enhance users' residential satisfaction in an environment. The study utilised the data collected among 494 respondents within five local government areas in Ibadan metropolis. Responses to users' satisfaction items variables are subjected to descriptive, correlation and regression analysis. The major finding of this research was that, the changing dynamics of socio-economic attributes of the users influence their expectation on the criteria of affordable housing. The socio-economic attributes significantly influence users' satisfaction on their current housing. The users are more aware about the facilities that should be associated with affordable housing and anything less than this makes them dissatisfied. The increasing level of education also proved to be a key factor influencing their awareness. The housing policy implications of these results were also highlighted.
\end{abstract}

Keywords: Affordable housing; Housing; Residential; Socio-economic attributes; Users' satisfaction

\section{INTRODUCTION}

The increase in housing demand in Nigerian urban centre resulted to many urban problems such as housing shortage and affordability (Olayiwola, Adeleye, \& Ogunshakin, 2005). At the beginning of the problem, affordable housing has primarily linked with economic factors only. Housing research focusing on the users, needs to analyse the importance of cultural, political, social, or economic factors that may likely influence the users' involvement in the housing market, be it affordable or for higher ends. Since affordable housing is not always a charitable or subsidized phenomenon, it must look into the likelihood to be accepted for satisfaction to the target users for a prolonged period. Therefore, study on socio-economic attributes of target group can be considered as a preliminary but significant stage in determining the characteristics of affordable housing as it can hint the success of the housing market. This is mainly to make housing not only affordable but also acceptable for satisfaction from other perspectives that can bring relief especially to the low and middle-income households in making decisions to enter the market of affordable housing.

The consequence of urban populations' growth at an alarming rate in many developed and developing world (UN-Habitat, 2011) with particular reference to Ibadan metropolis is the significant problem of meeting demand of affordable housing (Akinyode, 2016; Akinyode, Khan, \& Ahmad, 2015). Various factors have led Ibadan urban centre to become "users' city", and these factors include attractive cultural amenities and infrastructural facilities. Continuing 
inflow of people to Ibadan metropolis resulted to increase in housing demand followed by the increase in house rents and problem of housing affordability. House price increases for various reasons. The biggest is probably the land price. To meet with that, in most cases, location is compromised. Land is chosen far away from the popular workplaces. However, that also brings in other problems related with physical facilities. Lack of infrastructure makes them unattractive. Besides that, other tangible factors such as security, safety, and some other intangible factors such as taste, status etc. all contribute to the cost of the housing. If they are provided, that affects the price again, and an apparently affordable location cannot provide affordable price any more. Therefore, there is need for effective and workable housing delivery strategies and policy making. Pertinent information on housing affordability based on users' perspective might determine upgraded level of affordable housing, but failure in delivery strategy and policy making can still keep them unreachable for the target users. This study investigated both these issues in the wake of successfully delivering upgraded affordable housing to low and middle-income owners.

Referring to housing affordability in Ibadan urban centre specifically, users' behaviour as pertaining to factors being considered in housing affordability is not known. In view of this, policy decisions are often not very well informed to meet users' choices for affordable housing. The application of users' satisfaction on their current affordable housing in this study will unveil to other housing researchers and policy makers the users' perspectives and the factors that determine their housing affordability. This study can also provide detailed knowledge on housing typology and environment in Ibadan as the comprehensive coverage of the urban centre to provide ample information on the physical facilities of the housing in this context. Besides, detailed users' socio-economic data of the target group of low and middle-income people can also be used in designing, planning and implementing different housing related policies. Although the study is limited to Ibadan, the capital city of Oyo state, the Nigerian housing policy makers and that of other developing countries can have an insight that would be of relevant assistance and applicable in their housing affordability program through which affordable housing programme would be improved. The resulting knowledge will provide an evidence-based platform that is currently lacking for Nigerian housing policy and program development. However, the purpose of the study is not to produce definitive conclusions, or to provide generalizable results, but to provide a basis from which academics and practitioners in urban and regional planning, housing research and housing policy can begin to understand and explore this under-researched area. The study is therefore designed to fill an existing research gap in the field of housing research in Nigeria with particular reference to Ibadan, which will be of interest to Planners, Economists, Architects and researchers alike. This is to contribute and add to the existing housing research and literatures in housing studies in Nigeria.

This study aimed at correlating the influence of socio-economic attributes with users' satisfaction on their current affordable housing. The next section of this paper highlighted some features about the study area followed by the review of relevant literatures in section three. Section four of the paper discussed the methods and materials through which the objective is achieved. This is followed by section five that centred on the analysis and results while section six focused on the conclusion and housing policy implications.

\section{THE CONTEXT OF IBADAN}

Ibadan came into existence in 1829 (Akinyele, 1911) as a camp by the soldiers of the Ife, Ijebu and Oyo after they had successfully destroyed the neighbouring kingdom of Owu. Ibadan is the capital city of Oyo state located in south-western Nigeria. The city is located between latitude $7^{\circ} 19^{\prime}$ and $7^{\circ} 29^{\prime}$ North of the equator and longitude $3^{\circ} 47^{\prime}$ and 3०58' East of Greenwich meridian. 
This is at a distance of about 145 kilometres inland northeast of Lagos and 530 kilometres southwest of Abuja, the federal capital territory (FCT). Ibadan ranges in elevation from 150 metres in the valley area to 275 metres above sea level on the major north-south ridge that crosses its central part. Ibadan is naturally drained by four rivers with many tributaries namely Ona River in the North and West; Ogbere River towards the East; Ogunpa River flowing through the city and Kudeti River in the Central part of the metropolis.

Historically, Lagelu left Ile Ife with a handful of people from Ife, Oyo and Ijebu to establish a new city called Eba Odan, literally interpreted as 'between the forest and plains.' (Akinyele, 1911). According to Akinyele (1911), the first city was destroyed due to an occurrence at a masquerade festival when a masquerade was unintentionally undressed and disdainfully ridiculed by women and children in an open marketplace full of people. In Yorubaland, it was a scandal for women to see the eye of masquerade because masquerades were considered to be the dead forefathers who returned to the earth yearly to bless their offspring. The then Alaafin of Oyo named Sango ordered Eba Odan to be destroyed for committing such abominable deed. Lagelu and some of his people fled to a nearby hill and survived by eating oro fruit and snails. In addition, they cultivated the land to produce corn and millets and made pap meals known as eko been ate with roasted snails. They improvised using the snail shells to drink the liquid pap (eko).

Lagelu and his people later came down from the hill and established another city called Eba'dan. This was after the destruction of the first settlement near Awotan in the neighbourhood of Apete in Ido Local Government area. This is the present site of Ibadan and directly linked to several towns in Nigeria. The physical setting of the city consists of ridges of hills and the largest of these ridges lies in the central parts of the city such as Mapo, Mokola and Aremo. In 1893, Ibadan area became a British Protectorate after an agreement signed by Fijabi, the Baale of Ibadan with the British acting Governor of Lagos, George C. Denton on 15 August (Akinyele, 1911; Tomori, 2007). Ibadan became an administrative centre of the old Western Region since the period of British colonial rule. By then, Ibadan population had increased to 120,000. The British established the new colony to ease their commercial activities in the area which eventually led Ibadan to develop as major commercial centre that it is today.

According to 1963 national census figures, Ibadan was the most populous city in Oyo state with a population of 627,379 (NPC, 1991). It was the third most populous city in Nigeria, after Lagos and Kano and country's largest city by geographical area. The population of Ibadan reached 1,835,302 in 1991 (NPC, 1991) with population percentage increase of 65.82 between 1963 and 1991. According 2006 national census figures, Ibadan has reached a population of 2,559,853 comprises of eleven local government areas as shown in Figure 1 which is 75.49 percentage increase to 1963 population figures and 28.30 percentage increase to 1991 population figures. The 2016 and 2020 population of Ibadan was projected using 2006 population with 3 percent annual growth rate (NPC, 2010). The formula for the calculation for the population projection was $\mathrm{Pn}=\mathrm{Po}(1+\mathrm{r} / 100)^{\mathrm{n}}$ where ' $\mathrm{Pn}$ ' is the projected population for the target year, 'Po' is the base year population (2006), ' $r$ ' is the annual growth rate and ' $n$ ' is the year interval between the base year and the year to be projected (Akinyode \& Khan, 2013; Mehta, 1997). According to the projected method, the projected 2016 and 2020 Ibadan population are 3,440,228 and 3,872,007 with 25.59 and 33.89 percentage increase respectively. Five local government areas constituted Ibadan metropolis and these include Ibadan North denoted as 1, Ibadan North East as 2, Ibadan South East as 3, Ibadan South West as 4 while Ibadan North West is denoted as 5 . 
Figure 1: The 11 local government areas in Ibadan indicating local government areas 1 to 5 as the Ibadan Metropolis.

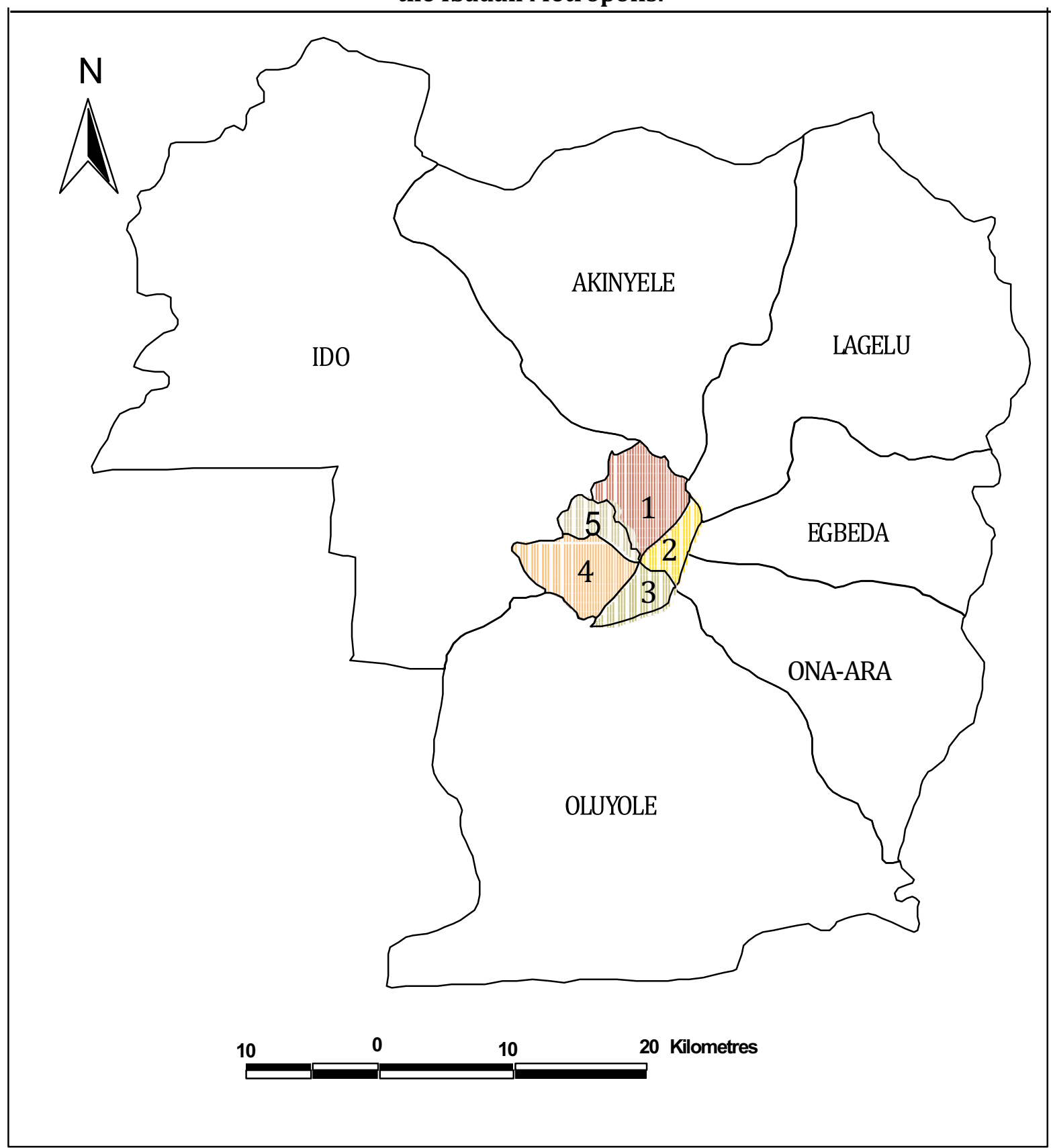

Source: Oyo State Ministry of Lands and Survey, 2005

The total land area is 3,080 square kilometres and its planning is considered as both planned and unplanned settlement. The unplanned area is largely within the old inner core area of the city inhabited mostly by the indigenes. The newly developing part of the city inhabited by both indigenes and non-indigenes is a combination of planned and unplanned areas. However, the so called planned areas are experiencing diverse degrees of unplanned growth as a result of ineffective development control (Akinyode, 2016; Akinyode \& Khan, 2016). The five local government areas that constitute the Ibadan metropolis have come under serious pressure of rapid urbanisation. More than half of the population live within the metropolis which is not more than 30 percent land coverage of the total Ibadan land area, 


\section{LITERATURE REVIEW}

Demographic factors play a key role in researches using users' satisfaction method. Different demographic variables can be used to comprehend and predict certain outcomes related to the dependent variables. In this research, the demographic variables could also play such a role as users from different demographic sub-group can have different opinions on the tangible and intangible variables of affordable housing. Different literatures examined the role of sociodemographic variables on housing affordability. Coolen, Boelhouwer, and van Driel (2002) and Heijs, van Deursen, Leussink, and Smeets (2011) asserted that socio-demographic characteristics had significant relationship to housing affordability. Manrique and Ojah (2003) discovered males were more probable of having a house. This was supported by Lauridsen and Skak (2007) who established that males were often greater with stable incomes that enhanced them the opportunity to acquire house than women. Gan, Hu, Gao, Kao, and A. Cohen (2013) investigated the impact of socio-economic attributes of homebuyers on home ownership and loan decisions in urban China. They discovered that male respondents who are the majority with higher levels of education owned a house and the socio-economic attributes such as educational attainment and household size had significant relationship with rejection for a housing loan. The socio-economic attributes of housing users had significant influence on home ownership thereby increased the number of housing in the housing market.

Lauridsen and Skak (2007) asserted that as the level of household head educational attainment changes, it contributed to housing affordability level. The household with higher level of educational attainment is likely to have better employment with higher income (Chua \& Miller, 2009; Constant, Roberts, \& Zimmermann, 2009) which was another factor that contributed to the user's housing affordability (Y. Huang \& Clark, 2002; Kurz \& Blossfeld, 2006). Kryger (2009) in his own study in Australia found that the rate of homeownership increased increasingly with age. Feijten, Mulder, and Baizán (2003) who affirmed that the age groups between 25 and 34 years had the utmost likelihood to become homeowners support this. The older the user the more likely to have higher incomes. This was because of long duration of their employment and increasing level of work experience. In view of this, the older users may likely be accessible to sufficient financial resources to owning a house (Chua \& Miller, 2009; Kurz \& Blossfeld, 2006; Wang, 2010).

In contrast, the type of household demographic in terms of marital status and household's size impacted on housing affordability but the age impacts was slightly less expected negative for both under age 30s and over age 60s (Bramley, 2011). The younger households and those that are of over aged were less likely to face housing affordability problem. Those in these age brackets were consider as dependants. Various scholars were of opinion that married users had a greater possibility of housing affordability compared to single and divorced users (Chua \& Miller, 2009; Del-Río \& Young, 2005; Hendershott, Ong, Wood, \& Flatau, 2009; H.-C. Huang, 2011; Y. Huang \& Clark, 2002; Lauridsen \& Skak, 2007). Employment status of the user affected a user's ability to partake in the labour market to earn an income and then possessed the ability to maintain housing costs. Bramley (2011) in his study discovered that unemployment rate in a community had a significant positive effect on housing affordability whereas user employment status negatively influenced housing affordability.

Like demographic variables, socio-economic attributes of users also play a significant role in comprehending and predicting outcomes of affordable housing in the context. The different variables can give view on the dependent variables from different perspective. That can give the researcher deeper understanding of the findings. Family economic status describes family's position, rank, class, status or economic position in a society (Mehdi, Laily, Mumtazah, \& 
Turiman, 2009) and determines the economic inequality among individuals and families. Income of the majority of households are too low and inputs to housing production are too expensive which has consequently led to the problem of inadequate provision and affordable housing to majority of households. Household's Income directly influences household's capability to purchase and make payment on house rents. Rent to income ratio also measures the level of housing affordability for the user. A maximum of 30 percent of a household's gross income is universally established for housing affordability in US, UK and Canada (Andrews, 1998; Fisher, Pollakowski, \& Zabel, 2009; Kutty, 2005; Onu \& Onu, 2012; Song, 2000). Housing is not affordable when monthly housing costs surpass 30.35 percent of household's income, Ndubueze (2009) in his study asserted that household's income positively and most influenced housing affordability while housing expenditure and household size were negatively influenced housing affordability. Arimah (1997) supported this assertion and included access to land and household size as other determinants factors to housing affordability. Income was to be the most imperative factor influencing home ownership and housing affordability according various scholars (Constant et al., 2009; Gan et al., 2013; Y. Huang \& Clark, 2002). An increase in the level of household income could positively influenced the user's home purchase decision and housing affordability.

Various other scholars used various indices in measuring housing affordability (Glaeser \& Gyourko, 2003; Quigley, 2007; Turner, 2003) and these include the housing price in relation to housing production costs, housing capital and house price. Each of the indicators to measure housing affordability has its benefits and restrictions. The most widely used and cited indicator of housing affordability was the rent to income ratio, due to its simplicity to calculate and ease of understanding. However, it did not fully depict a user's ability to pay for housing and nonhousing expenses all together. There is likelihood that some low-income users may not be capable of paying between 25 percent and 30 percent of their income on housing without having financial stress with very low standard of living. Whereas high income users might be capable of paying up to 50 percent of their income on housing without having financial stress and at the same time maintain a high standard of living (Robinson, Scobie, \& Hallinan, 2006; UN-Habitat, 2011). This approach in measuring housing affordability also failed to be concerned with user's wellbeing and satisfaction by not taking into consideration differences in housing quality in terms of housing physical attributes, provided amenities and facilities and household size. Concentrating on definite rent payments gave no room for variances in housing quality and users' satisfaction within the housing market. To overcome this problem is by examining the users' standard of living through their socio-economic attributes with a view of determining users' residential satisfaction in an environment. This will give better understanding of how users' socio-economic attributes can be integrated into housing policy making.

\section{METHODS AND MATERIALS}

The study used users' satisfaction with the adoption of quantitative research approach to achieve the objective. Quantitative data was collected through questionnaire survey. Descriptive, correlation and regression analysis techniques were employed to analyse the data. The study started with empirical observation that led to identifying problems.

\section{Participants}

500 respondents within the five local government areas of Ibadan metropolis were sampled. There were 113 respondents in Ibadan North local government area, 119 respondents in North-East local government area, 59 respondents in North-West local government area, 101 respondents in South-East local government area and 108 respondents in South-West local 
government area. Through verification of the questionnaires, six questionnaires were incomplete and then discarded. The remaining 494 questionnaires representing 494 respondents were used in this study.

\section{Analysis}

This study employed Pearson correlation to determine the relationship between users' socioeconomic attributes and housing satisfaction on their current affordable housing. The performance of regression analysis was to ascertain the strength and level of the factors that influences housing satisfaction. The employment of descriptive method was to explain the socio-economic attributes of the participants and the impact of socio-economic attributes on users' satisfaction on their current affordable housing. Descriptive statistics such frequency tables and percentage were used for illustration purposes. The results were used to generalise or make claims about a population (Creswell, 2003).

\section{ANALYSIS AND RESULTS}

The study aimed at correlating the socio-economic attributes with users' satisfaction on their currently available affordable housing. The socio-economic attributes were discussed through descriptive analysis. Afterwards, a correlation and regression analysis were performed along with the dependent variable (users' satisfaction). That led to certain interesting findings which include the most influencing socio-economic attributes that affect users' satisfaction. Means ttest was performed at the beginning to check whether all the 8 item variables are eligible for further analysis. They all proved to be significant as shown in Table 1.

Table 1: Mean's t-test for socio-economic attributes

\begin{tabular}{|l|c|c|c|c|c|c|}
\hline \multicolumn{2}{|l|}{ One-Sample Test } & \multicolumn{5}{c|}{ Test Value = 0 } \\
\hline \multicolumn{1}{|c|}{ Item Variables } & $\mathrm{t}$ & $\mathrm{df}$ & $\begin{array}{c}\text { Sig. (2- } \\
\text { tailed) }\end{array}$ & $\begin{array}{c}\text { Mean } \\
\text { Difference }\end{array}$ & $\begin{array}{c}\text { 95\% Confidence } \\
\text { Interval of the } \\
\text { Difference }\end{array}$ \\
\cline { 5 - 8 } & & & & & $\begin{array}{c}\text { Lowe } \\
\text { r }\end{array}$ & Upper \\
\hline Respondent's Sex & 64.633 & 493 & $\mathbf{. 0 0 0}$ & 1.447 & 1.40 & 1.49 \\
\hline Respondent's Age & 63.665 & 493 & $\mathbf{. 0 0 0}$ & 3.387 & 3.28 & 3.49 \\
\hline Marital Status & 51.435 & 493 & $\mathbf{. 0 0 0}$ & 3.854 & 3.71 & 4.00 \\
\hline $\begin{array}{l}\text { Educational } \\
\text { Attainment }\end{array}$ & 55.918 & 493 & $\mathbf{. 0 0 0}$ & 2.407 & 2.32 & 2.49 \\
\hline Employment Status & 64.919 & 493 & $\mathbf{. 0 0 0}$ & 2.255 & 2.19 & 2.32 \\
\hline Job Rank Status & 41.450 & 493 & $\mathbf{. 0 0 0}$ & 1.350 & 1.29 & 1.41 \\
\hline $\begin{array}{l}\text { Estimated Monthly } \\
\text { Income }\end{array}$ & 38.532 & 493 & $\mathbf{. 0 0 0}$ & 1.476 & 1.40 & 1.55 \\
\hline $\begin{array}{l}\text { Did your Employer } \\
\text { give } \\
\text { accommodation }\end{array}$ & 53.467 & 493 & $\mathbf{. 0 0 0}$ & 1.275 & 1.23 & 1.32 \\
\hline
\end{tabular}

\section{Validity and Reliability of Data}

Some statistical validity and reliability test were done in order to make sure the statistical data were significant. The validity in this study was based on scores, instruments or research designs through Kaiser-Meyer-Olkin (KMO) measure of sampling adequacy and Bartlett's test of sphericity. Cronbach's Alpha was used to access the internal consistent reliability of the 
survey instrument. In this study, both the Reliability and Adequacy Test were performed and the result of the Cronbach's coefficient alpha of Reliability test indicated greater reliability while Kaiser-Meyer-Olkin (KMO) of Validity test also showed that the instrument truly measured what it supposed to measure. The Cronbach's alpha coefficient value of 0.753 was considered sufficiently reliable and good internal consistency. This followed the recommendation of some scholars that claimed the Cronbach's Alpha coefficient ranges between scale of 0.50 and 0.80 should be considered sufficiently reliable and good internal consistency for an exploratory study such as this (Foubert, Tepper, \& Morrison, 1998; Hair, Black, Babin, \& Anderson, 2010; Khozaei, Ayub, Hassan, \& Khozaei, 2010; Newton \& Meyer, 2010; Toyin Sawyerr \& Yusof, 2013). The study also recorded higher respondents of 494 administered questionnaires with KMO value of 0.835 . This signifies reliable, adequate and valid survey sampling (Field, 2009).

\section{Participants' socio-economic attributes}

The 55.30 percent of the respondents were male while 44.70 percent were females as shown in Table 2. About 26.90 percent of the respondents were within the age group 31 - 40 years followed by age group 21-30 years that took 25.10 percent while those that were above 50 years amounted to 24.30 percent of the total respondents. The respondents that were less than 21 years old took only 2.80 percent of the total respondents. The working class among the respondents constituted about 72.90 percent while remaining 27.10 were either the aged people that were above 50 years old or less than 21 years old. This implied that a larger population of the respondents between age 21 and 50 years were within the working class who were matured and old enough to rent or own a house. This supported the view of some scholars that opined that the older the users within the working age, the likelihood to have higher incomes and become homeowners (Chua \& Miller, 2009; Feijten et al., 2003; Kryger, 2009; Kurz \& Blossfeld, 2006; Wang, 2010). These age group can determine whether they can afford, accept, prefer and satisfy with a particular residential neighbourhood or not. Most of the respondents were married contributing about 62.30 percent. This was followed by the single contributing 21.70 percent of the total respondents while widow or widower contributed 8.90 percent and married but single contributed 04.90 percent as shown in Table 2. The divorcee took the least percentage of 2.20 percent of the total respondents.

Majority of the respondents obtained elementary education that comprises of primary, secondary, modern and Grade II educations. Out of the 494 respondents, 58.70 percent respondents obtained elementary education. This was followed by NCE/OND which was 14.20 percent of the total respondents as indicated in Table 2. About 13.60 percent obtained HND/BSc and 03.20 percent obtained postgraduate certificates which can either be at MSc or PhD level whereas 10.30 percent had no formal education. It can be inferred that the low level of educational attainment of the respondents had influence in their income level, employment status, official status and their income group as well as the type of housing and the environment they were living. This was in line with the assertion of some scholars that, the changes in educational attainment was likely to have better employment with higher income that contributed to the user's housing affordability (Chua \& Miller, 2009; Constant et al., 2009; Kurz \& Blossfeld, 2006; Lauridsen \& Skak, 2007). 
Table 2: Respondents' Socio-economic and demographic attributes

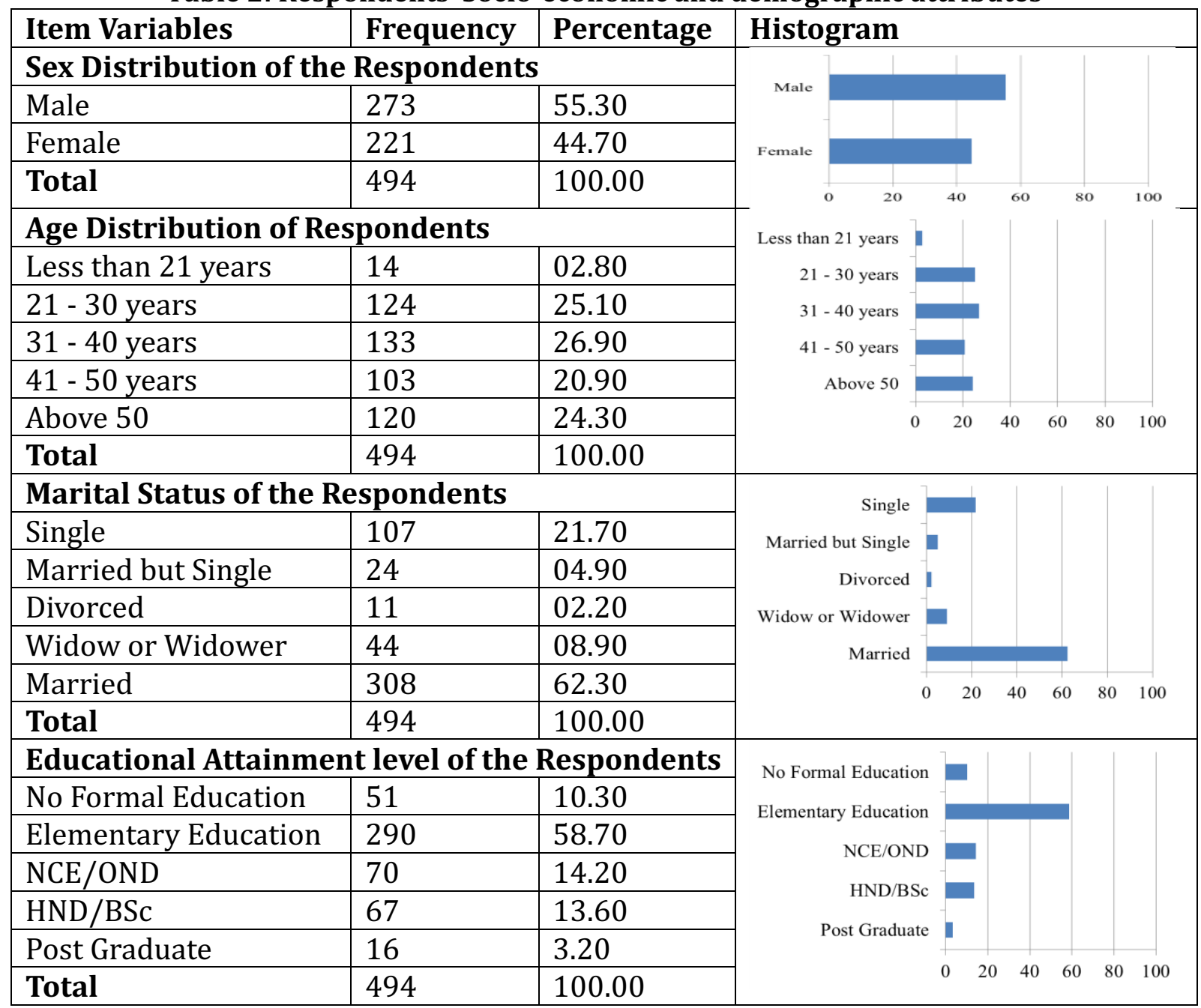

As depicted in Table 3, majority of the respondents were self-employed. About 70.00 percent of the respondents were self-employed while 13.00 percent, 07.70 percent and 07.70 percent were government, unemployed and company employees respectively. The employment status of the respondents reflected in the higher proportion of the respondents that were not government workers as shown in the official status of the respondents. This category of the respondents engaged themselves in trading and artisan jobs. The Employment status of the respondents reflected in their estimated monthly income. Their official status also reflected in the greater proportion of the respondents that can be termed as the low-income earners. About 78.30 percent of the respondents were not government workers. Only 01.40 percent and 10.50 percent constituted the management and senior staff respectively. Senior staff was more than the junior staff. This was because; some teachers in private schools with no specific grade level counted themselves as senior staff. It was impossible to distinguish the senior staff from junior staff in this regards where there was no specific grade level in operation. 
Table 3: Respondents' Socio-economic attributes

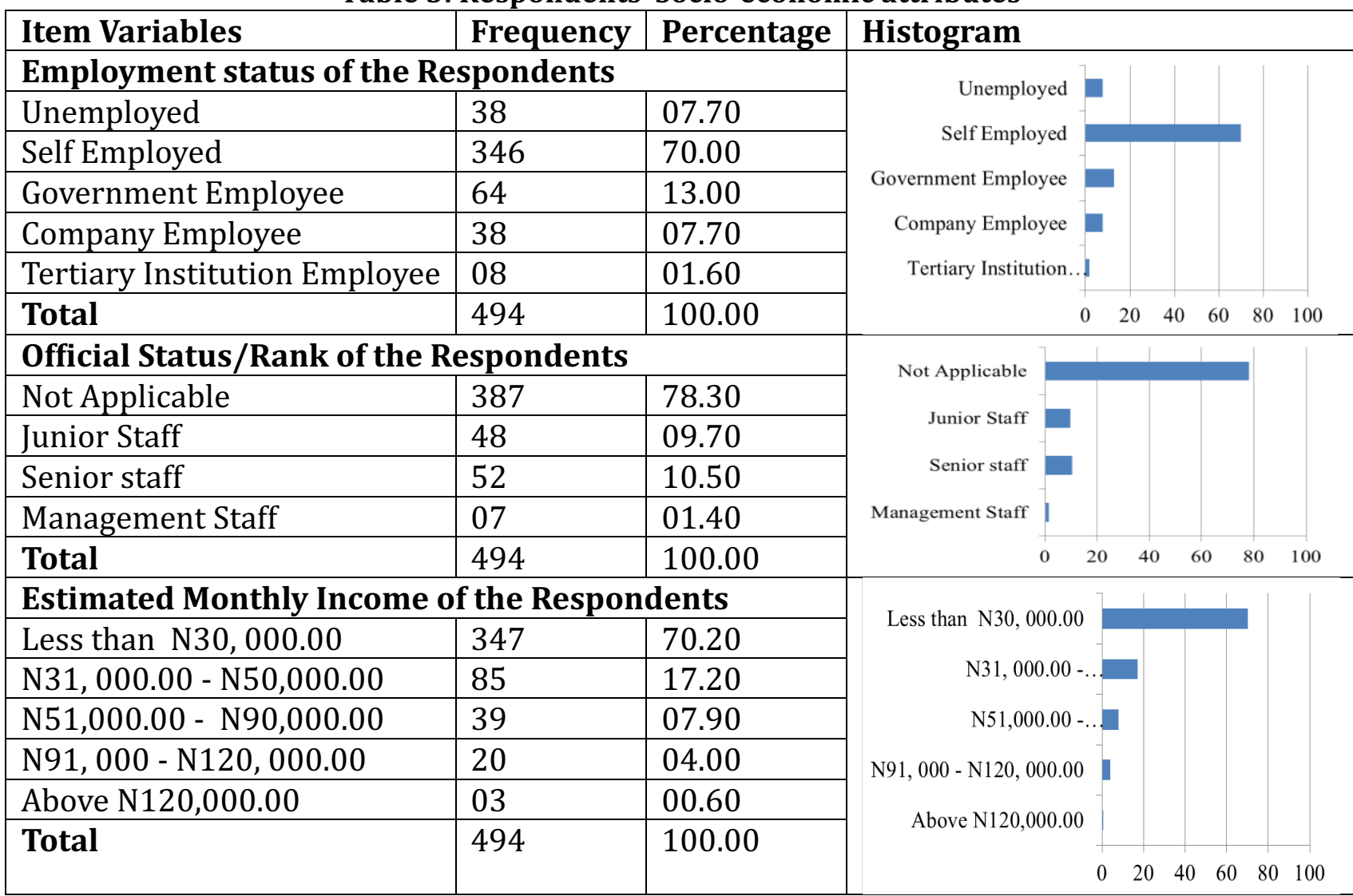

Majority of the respondents earned less than $\$ 30,000.00$ monthly and this amounted to 72.20 percent of the entire sampled respondents. In view of this, majority of the respondents were grouped within the low-income population. This was followed by those that earned between $\$ 30,000.00$ and $\$ 50,000.00$ which amounted to 17.20 percent of the total respondents. About 07.90 percent and 04.00 percent were the respondents that earned between $\$ 51,000.00$ and $\$ 90,000.00$ and between $\$ 91,000.00$ and $\$ 120,000.00$ respectively as shown in Table 3 while only 0.6 percent earned above $\$ 120,000.00$. Estimated monthly income was used to group the respondents into different income earner groups as low income, middle income and highincome earners. The respondents that earned between less than $\$ 10,000.00$ and $\$ 50,000.00$ were grouped as low income earners, those that earned between $\$ 51,000.00$ and $\$ 90,000.00$ were grouped as middle income earners while the respondents that earned up to $\$ 91$ and above were grouped as high income earners.

Based on this grouping, the majority of the respondents were low-income earners constituted 87.40 percent of the total sampled respondents. The middle-income earners followed with 7.90 percent while the least respondents among the sampled survey was high-income earners that amounted to 4.70 percent of the total respondents. This concluded the demographic analysis. Seven out of eight item variables were discussed. The eighth one, i.e. 'Did your employer give you accommodation', was excluded through qualitative judgement. However, it was included during the next step of correlation and regression in case it had any quantitative significance.

\section{Correlating socio-economic attributes with users' residential satisfaction}

The socio-economic data were correlated with the dependent variable 'users' residential satisfaction' and summarised in Table 4. Too many significant data were likely to create confusion. Therefore, regression analysis was performed in order to find the interdependency 
of the variables to determine and exclude those who created unnecessary influence from the more significant ones. The Table 5 showed the backward regression analysis in order to find out the most significant variables but in an order of their significance. For example, Model 1 in Table 5 showed all 8 variables, while Model 2 shows 7. 'Age' has been removed as being the least significant. Model 3 removed the item variable 'Marital Status', and so on. Finally, only two item variables were left in Model 7 as shown in Table 5

Table 4: Correlation Analysis between Socio-economic data and Users' Residential Satisfaction

\begin{tabular}{|c|c|c|c|c|c|c|c|c|c|c|}
\hline & & Sex & Age & $\begin{array}{l}\text { Marit } \\
\text { al } \\
\text { Statu } \\
\text { s }\end{array}$ & $\begin{array}{l}\text { Educatio } \\
\text { nal } \\
\text { Attainme } \\
\text { nt }\end{array}$ & $\begin{array}{l}\text { Employm } \\
\text { ent Status }\end{array}$ & $\begin{array}{l}\text { Job } \\
\text { Ran } \\
\mathbf{k}\end{array}$ & $\begin{array}{l}\text { Month } \\
\text { ly } \\
\text { Incom } \\
\text { e }\end{array}$ & $\begin{array}{l}\text { Accommodat } \\
\text { ion by by } \\
\text { Employer }\end{array}$ & $\begin{array}{l}\text { Users' } \\
\text { Residenti } \\
\text { al } \\
\text { Satisfacti } \\
\text { on }\end{array}$ \\
\hline \multirow[t]{2}{*}{ Sex } & $r$ & 1 & .043 & $.123^{* *}$ & $-.204^{* *}$ & $-.171^{* *}$ & $\begin{array}{l}- \\
.210\end{array}$ & $-.173^{* *}$ & $-.229^{* *}$ & .001 \\
\hline & $\alpha$ & & .337 & .006 & .000 & .000 & .000 & .000 & .000 & .977 \\
\hline \multirow[t]{2}{*}{ Age } & $\mathrm{r}$ & .043 & 1 & $.508^{* *}$ & $-.184^{* *}$ & .072 & .107 & $.109^{*}$ & .063 & -.065 \\
\hline & $\alpha$ & .337 & & .000 & .000 & .111 & .017 & .015 & .163 & .148 \\
\hline \multirow[t]{2}{*}{$\begin{array}{l}\text { Marital } \\
\text { Status }\end{array}$} & $r$ & .123 & .508 & 1 & $-.091^{*}$ & $.154^{* *}$ & .128 & $.138^{* *}$ & .059 & -.062 \\
\hline & $\alpha$ & .006 & .000 & & .043 & .001 & .004 & .002 & .188 & .167 \\
\hline \multirow[t]{2}{*}{$\begin{array}{l}\text { Educational } \\
\text { Attainment }\end{array}$} & $r$ & $\begin{array}{l}- \\
.204\end{array}$ & $\begin{array}{l}- \\
.184\end{array}$ & $-.091^{*}$ & 1 & $.540^{* *}$ & .661 & $.624^{* *}$ & $.583^{* *}$ & -.059 \\
\hline & $\alpha$ & .000 & .000 & .043 & & .000 & .000 & .000 & .000 & .191 \\
\hline \multirow[t]{2}{*}{$\begin{array}{l}\text { Employment } \\
\text { Status }\end{array}$} & $r$ & 171 & .072 & $.154^{* *}$ & $.540^{* *}$ & 1 & .704 & $.550^{* *}$ & $.646^{* *}$ & $-.099^{*}$ \\
\hline & $\alpha$ & .000 & .111 & .001 & .000 & & .000 & .000 & .000 & .028 \\
\hline \multirow[t]{2}{*}{ Job Rank } & $r$ & -210 & .107 & $.128^{* *}$ & $.661^{* *}$ & $.704^{* *}$ & 1 & $.720^{* *}$ & $.758^{* *}$ & $-.146^{* *}$ \\
\hline & $\alpha$ & .000 & .017 & .004 & .000 & .000 & & .000 & .000 & .001 \\
\hline \multirow[t]{2}{*}{$\begin{array}{l}\text { Monthly } \\
\text { Income }\end{array}$} & $r$ & -173 & .109 & $.138^{* *}$ & $.624^{* *}$ & $.550^{* *}$ & .720 & 1 & $.622^{* *}$ & $-.212^{* *}$ \\
\hline & $\alpha$ & .000 & .015 & .002 & .000 & .000 & .000 & & .000 & .000 \\
\hline \multirow[t]{2}{*}{$\begin{array}{l}\text { Accommodat } \\
\text { ion by } \\
\text { Employer }\end{array}$} & $\mathrm{r}$ & .229 & .063 & .059 & $.583^{* *}$ & $.646^{* *}$ & .758 & $.622^{* *}$ & 1 & $-.133^{* *}$ \\
\hline & $\alpha$ & .000 & .163 & .188 & .000 & .000 & .000 & .000 & & .003 \\
\hline \multirow[t]{2}{*}{$\begin{array}{l}\text { Users' } \\
\text { Residential } \\
\text { Satisfaction }\end{array}$} & $\mathrm{r}$ & .001 & .065 & -.062 & -.059 & $-.099^{*}$ & .146 & $-.212^{* *}$ & $-.133^{* *}$ & 1 \\
\hline & $\alpha$ & .977 & .148 & .167 & .191 & .028 & .001 & .000 & .003 & \\
\hline \multicolumn{11}{|c|}{$\mathrm{r}=$ Coefficient of Pearson's Correlation } \\
\hline \multicolumn{11}{|c|}{$\mathrm{N}=494$} \\
\hline
\end{tabular}


Table 5: Backward Regression Analysis of Socio-economic Data

\begin{tabular}{|c|c|c|c|c|c|c|}
\hline \multirow[t]{2}{*}{ Model } & \multirow[t]{2}{*}{ Item Variables } & \multicolumn{2}{|c|}{$\begin{array}{l}\text { Unstandardized } \\
\text { Coefficients }\end{array}$} & \multirow{2}{*}{$\begin{array}{l}\begin{array}{l}\text { Standardized } \\
\text { Coefficients }\end{array} \\
\text { Beta }\end{array}$} & \multirow[t]{2}{*}{$\mathbf{t}$} & \multirow[t]{2}{*}{ Sig. } \\
\hline & & $\mathrm{B}$ & Std. Error & & & \\
\hline \multirow[t]{9}{*}{1} & (Constant) & 2.382 & .170 & & 14.043 & .000 \\
\hline & Respondent's Sex & -.037 & .059 & -.029 & -.635 & .526 \\
\hline & Respondent's Age & -.002 & .029 & -.004 & -.080 & .937 \\
\hline & Marital Status & -.002 & .020 & -.005 & -.096 & .923 \\
\hline & $\begin{array}{l}\text { Educational } \\
\text { Attainment }\end{array}$ & .087 & .045 & .131 & 1.948 & .052 \\
\hline & Employment Status & .015 & .053 & .018 & .281 & .779 \\
\hline & Job Rank & -.030 & .075 & -.034 & -.396 & .692 \\
\hline & Monthly Income & -.192 & .051 & -.257 & -3.787 & .000 \\
\hline & $\begin{array}{l}\text { Accommodation by } \\
\text { Employer }\end{array}$ & -.049 & .085 & -.041 & -.579 & .563 \\
\hline \multirow[t]{8}{*}{2} & (Constant) & 2.376 & .152 & & 15.656 & .000 \\
\hline & Respondent's Sex & -.037 & .059 & -.029 & -.634 & .526 \\
\hline & Marital Status & -.003 & .018 & -.007 & -.148 & .883 \\
\hline & $\begin{array}{l}\text { Educational } \\
\text { Attainment }\end{array}$ & .088 & .043 & .133 & 2.056 & .040 \\
\hline & Employment Status & .015 & .053 & .018 & .283 & .777 \\
\hline & Job Rank & -.031 & .075 & -.035 & -.408 & .684 \\
\hline & Monthly Income & -.192 & .050 & -.258 & -3.818 & .000 \\
\hline & $\begin{array}{l}\text { Accommodation by } \\
\text { Employer }\end{array}$ & -.050 & .085 & -.042 & -.583 & .560 \\
\hline \multirow[t]{7}{*}{3} & (Constant) & 2.368 & .142 & & 16.701 & .000 \\
\hline & Respondent's Sex & -.038 & .058 & -.030 & -.662 & .509 \\
\hline & $\begin{array}{l}\text { Educational } \\
\text { Attainment }\end{array}$ & .090 & .041 & .135 & 2.176 & .030 \\
\hline & Employment Status & .014 & .053 & .017 & .266 & .791 \\
\hline & Job Rank & -.032 & .075 & -.036 & -.425 & .671 \\
\hline & Monthly Income & -.193 & .050 & -.259 & -3.885 & .000 \\
\hline & $\begin{array}{l}\text { Accommodation by } \\
\text { Employer }\end{array}$ & -.049 & .085 & -.041 & -.576 & .565 \\
\hline \multirow[t]{6}{*}{4} & (Constant) & 2.381 & .132 & & 17.988 & .000 \\
\hline & Respondent's Sex & -.038 & .058 & -.030 & -.662 & .508 \\
\hline & $\begin{array}{l}\text { Educational } \\
\text { Attainment }\end{array}$ & .091 & .041 & .137 & 2.214 & .027 \\
\hline & Job Rank & -.025 & .070 & -.029 & -.357 & .721 \\
\hline & Monthly Income & -.193 & .050 & -.259 & -3.884 & .000 \\
\hline & $\begin{array}{l}\text { Accommodation by } \\
\text { Employer }\end{array}$ & -.044 & .083 & -.037 & -.531 & .595 \\
\hline \multirow[t]{5}{*}{5} & (Constant) & 2.385 & .132 & & 18.095 & .000 \\
\hline & Respondent's Sex & -.038 & .058 & -.030 & -.654 & .513 \\
\hline & $\begin{array}{l}\text { Educational } \\
\text { Attainment }\end{array}$ & .087 & .039 & .131 & 2.200 & .028 \\
\hline & Monthly Income & -.200 & .046 & -.268 & -4.354 & .000 \\
\hline & $\begin{array}{l}\text { Accommodation by } \\
\text { Employer }\end{array}$ & -.059 & .071 & -.049 & -.827 & .409 \\
\hline \multirow[t]{4}{*}{6} & (Constant) & 2.318 & .082 & & 28.137 & .000 \\
\hline & $\begin{array}{l}\text { Educational } \\
\text { Attainment }\end{array}$ & .089 & .039 & .134 & 2.260 & .024 \\
\hline & Monthly Income & -.199 & .046 & -.268 & -4.354 & .000 \\
\hline & $\begin{array}{l}\text { Accommodation by } \\
\text { Employer }\end{array}$ & -.053 & .071 & -.044 & -.751 & .453 \\
\hline \multirow[t]{3}{*}{7} & (Constant) & 2.293 & .076 & & 30.336 & .000 \\
\hline & $\begin{array}{l}\text { Educational } \\
\text { Attainment }\end{array}$ & .079 & .037 & .120 & 2.133 & .033 \\
\hline & Monthly Income & -.213 & .042 & -.287 & -5.102 & .000 \\
\hline
\end{tabular}

The excluded variables were shown in the following Table 6, where their sequence of exclusion can be understood. This was to give the idea of which variable performed the worst, which one was next to the worst and so on. 
Akinyode, B. F. (2017). Correlating Socio-Economic Attributes With Users' Residential Satisfaction: Implications For Housing Policy In Ibadan Metropolis, Nigeria. Advances in Social Sciences Research Journal, 4(12) 160-175.

Table 6: Excluded variables for Socio-economic Data

\begin{tabular}{|c|c|c|c|c|c|c|}
\hline Model & Item Variables & Beta In & $\mathbf{t}$ & Sig. & $\begin{array}{l}\text { Partial } \\
\text { Correlation }\end{array}$ & $\begin{array}{l}\text { Collinearity } \\
\text { Statistics } \\
\text { Tolerance }\end{array}$ \\
\hline 2 & Respondent's Age & $-.004 \mathrm{a}$ & -.080 & .937 & -.004 & .679 \\
\hline \multirow[t]{2}{*}{3} & Respondent's Age & $-.007 \mathrm{~b}$ & -.137 & .891 & -.006 & .848 \\
\hline & Marital Status & $-.007 b$ & -.148 & .883 & -.007 & .875 \\
\hline \multirow[t]{3}{*}{4} & Respondent's Age & $-.006^{c}$ & -.127 & .899 & -.006 & .849 \\
\hline & Marital Status & $-.005^{c}$ & -.110 & .912 & -.005 & .891 \\
\hline & Employment Status & $.017 \mathrm{c}$ & .266 & .791 & .012 & .470 \\
\hline \multirow[t]{4}{*}{5} & Respondent's Age & $-.009^{d}$ & -.184 & .854 & -.008 & .872 \\
\hline & Marital Status & $-.008^{\mathrm{d}}$ & -.163 & .871 & -.007 & .912 \\
\hline & Employment Status & $.008^{\mathrm{d}}$ & .132 & .895 & .006 & .529 \\
\hline & Job Rank Status & $-.029 \mathrm{~d}$ & -.357 & .721 & -.016 & .301 \\
\hline \multirow[t]{5}{*}{6} & Respondent's Age & $-.010 \mathrm{e}$ & -.209 & .835 & -.009 & .874 \\
\hline & Marital Status & $-.011^{\mathrm{e}}$ & -.248 & .804 & -.011 & .928 \\
\hline & Employment Status & $.008 \mathrm{e}$ & .136 & .892 & .006 & .529 \\
\hline & Job Rank Status & $-.027 \mathrm{e}$ & -.342 & .733 & -.015 & .302 \\
\hline & Respondent's Sex & $-.030 \mathrm{e}$ & -.654 & .513 & -.030 & .940 \\
\hline \multirow[t]{6}{*}{7} & Respondent's Age & $-.013^{f}$ & -.289 & .773 & -.013 & .884 \\
\hline & Marital Status & $-.013^{f}$ & -.280 & .780 & -.013 & .930 \\
\hline & Employment Status & $-.010^{f}$ & -.182 & .856 & -.008 & .634 \\
\hline & Job Rank Status & $-.047^{f}$ & -.678 & .498 & -.031 & .408 \\
\hline & Respondent's Sex & $-.025^{f}$ & -.555 & .579 & -.025 & .955 \\
\hline & $\begin{array}{l}\text { Did your Employer give you } \\
\text { accommodation }\end{array}$ & $-.044 f$ & -.751 & .453 & -.034 & .551 \\
\hline \multicolumn{7}{|c|}{$\begin{array}{l}\text { a. Predictors in the Model: (Constant), Did your Employer give you accommodation, Marital Status, } \\
\text { Respondent's Sex, Educational Attainment, Employment Status, Estimated Monthly Income, Job Rank } \\
\text { Status }\end{array}$} \\
\hline \multicolumn{7}{|c|}{$\begin{array}{l}\text { b. Predictors in the Model: (Constant), Did your Employer give you accommodation, Respondent's Sex, } \\
\text { Educational Attainment, Employment Status, Estimated Monthly Income, Job Rank Status }\end{array}$} \\
\hline \multicolumn{7}{|c|}{$\begin{array}{l}\text { c. Predictors in the Model: (Constant), Did your Employer give you accommodation, Respondent's Sex, } \\
\text { Educational Attainment, Estimated Monthly Income, Job Rank Status }\end{array}$} \\
\hline \multicolumn{7}{|c|}{$\begin{array}{l}\text { d. Predictors in the Model: (Constant), Did your Employer give you accommodation, Respondent's Sex, } \\
\text { Educational Attainment, Estimated Monthly Income }\end{array}$} \\
\hline \multicolumn{7}{|c|}{$\begin{array}{l}\text { e. Predictors in the Model: (Constant), Did your Employer give you accommodation, Educational } \\
\text { Attainment, Estimated Monthly Income }\end{array}$} \\
\hline \multicolumn{7}{|c|}{$\begin{array}{l}\text { f. Predictors in the Model: (Constant), Educational Attainment, Estimated Monthly Income } \\
\text { g. Dependent Variable: Users' Residential Satisfaction }\end{array}$} \\
\hline
\end{tabular}

The significance level of the final two remaining item variables demanded explanations, which consequently generated the major findings. While it was easier to assume that the more the income, the less will be the satisfaction level among the users of these affordable housing. However, the variable 'educational attainment' demanded more explanation. It appeared that people's educational level is increasing, but that was not immediately changing the economic status, it certainly affecting the satisfaction level. This notion had been explained more in the conclusion and housing policy implications in the next section.

\section{CONCLUSION AND HOUSING POLICY IMPLICATIONS}

It was clear from the demographic data that these people are poor. In fact, it is not surprising at all because only the low-income people will search for affordable housing. However, one significant issue is that the educational level of these low income users is getting higher. That means, they have more knowledge than before, and their expectation have gone higher too. Therefore, the current housing conditions cannot satisfy them anymore. The strong negative correlation between the educational level and users' satisfaction gives a clearer picture of this 
issue. The major finding of this research was that, the changing dynamics of socio-economic attributes of the users influence their expectation on the criteria of affordable housing. The socio-economic attributes significantly influence users' residential satisfaction on their current housing. The users are more aware about the facilities that should be associated with affordable housing and anything less than this makes them dissatisfied. The increasing level of education also proved to be a key factor influencing their awareness.

High education leads to higher economic status in course of time. Nevertheless, an immediate effect is that education also adds to the value of lifestyle. Educated people probably are ready to sacrifice other luxuries but prefer to spend more on housing, either in terms of rent or in terms of ownership. However, it is not a quick process to move to a better house immediately. Sometimes it takes generations. Nevertheless, as they became more aware, that gives them a drive to look for better lifestyle in a better house. Therefore, though still economically at a lower end, educated people will still search for a better house. The benchmark of the quality of affordable housing can then rise because of the rise of the overall level of education. It can therefore be inferred that economy proves affordability but education adds to the value of users' lifestyle and hence increases expectation in the quality of housing.

Overall improvement of housing standard irrespective of socio-economic classes is therefore necessary for a nation to move forward. Accessibility to decent but affordable housing provision is the key for countries like Nigeria, where the low-income group occupy the majority of the demographic distribution. Improvement in housing stock along with wellplanned acceptable standard of infrastructures and affordable cost becomes strategically important social and economic investment. In view of this, affordable housing delivery that will give satisfaction to different users in Ibadan metropolis should be given urgent attention. Government should be of assistance to the private housing investors for affordable housing delivery so that every individual or household, irrespective of affluence, can live in a decent housing environment that will satisfy them. This can be in form of granting loan with low interest and joining as partners with the private investors. This will consequently make rent control to be effective and improve users' living standard, influence their health, welfare and productivity.

\section{References}

Akinyele, I. B. (1911). Iwe Itan Ibadan (History of Ibadan). Nigeria.

Akinyode, B. F. (2016). Effects of Urbanisation on Urban Housing among Low Income Households in Nigeria. British Journal of Humanities and Social Sciences, 14(1), 10-22.

Akinyode, B. F., \& Khan, T. H. (2013). Evaluation of Housing Provision during the Last Two Decades in the Context of Nigeria: A Case Study in Ogbomoso. International Journal of Humanities and Social Science, 3(15), $204-215$.

Akinyode, B. F., \& Khan, T. H. (2016). Influence of Estate Agents and Building Plan Approval Cost On Housing Affordability in Developing Cities. IOSR Journal Of Humanities And Social Science, 21(9:8), 47-55. doi:10.9790/0837-2109084755

Akinyode, B. F., Khan, T. H., \& Ahmad, A. S. B. H. (2015). Socio-Economic Factors in Measuring the Demand for Residential Neighbourhood in Nigeria. Asian Social Science, 11(12), 235-247. doi:10.5539/ass.v11n12p235

Andrews, N. O. (1998). Housing Affordability and Income Mobility for the Poor: A Review of Trends and Strategies. Retrieved from http://www.nlihc.org/mahn/afford.htm

Arimah, B. C. (1997). The Determinants of Housing Tenure Choice in Ibadan, Nigeria. Urban Studies, 34(1), 105124. doi:10.1080/0042098976294

Bramley, G. (2011). Affordability, poverty and housing need: triangulating measures and standards. Journal of Housing and the Built Environment, 27(2), 133-151. doi:10.1007/s10901-011-9255-4 
Chua, J., \& Miller, P. W. (2009). The Impact of Immigrant Status on Home Ownership in Australia. International Migration, 47(2), 155-192. doi:10.1111/j.1468-2435.2008.00504.x

Constant, A. F., Roberts, R., \& Zimmermann, K. F. (2009). Ethnic Identity and Immigrant Homeownership. Urban Studies, 46(9), 1879-1898. doi:10.1177/0042098009106022

Coolen, H., Boelhouwer, P., \& van Driel, K. (2002). Values and goals as determinants of intended tenure choice. Journal of Housing and the Built Environment, 17(3), 215-236.

Creswell, J. W. (2003). Research Design: Qualitative, Quantitative and Mixed Methods Approaches. California, USA: SAGE Publication.

Del-Río, A., \& Young, G. (2005). The determinants of unsecured borrowing: evidence from the British Household Panel Survey.

Feijten, P., Mulder, C. H., \& Baizán, P. (2003). Age differentiation in the effect of household situation on first-time homeownership. Journal of Housing and the Built Environment, 18(3), 233-255.

Field, A. (2009). Discovering Statistics Using SPSS (Third ed.). London: SAGE Publications Ltd.

Fisher, L. M., Pollakowski, H. O., \& Zabel, J. (2009). Amenity-Based Housing Affordability Indexes. Real Estate Economics, 37(4), 705-746.

Foubert, J. D., Tepper, R., \& Morrison, D. (1998). Predictors of student satisfaction in university residence halls. The Journal of College and University Student Housing, 27(1), 41-46.

Gan, C., Hu, B., Gao, C., Kao, B., \& A. Cohen, D. (2013). An empirical analysis of homeownership in urban China. Journal of Asia Business Studies, 8(1), 1-17. doi:10.1108/jabs-01-2012-0005

Glaeser, E. L., \& Gyourko, J. (2003). The impact of building restrictions on housing affordability. Economic Policy Review, 9(2).

Hair, J. F., Black, W. C., Babin, B. J., \& Anderson, R. E. (2010). Multivariate Data Analysis: Overview of Multivariate Methods (Seventh Edition ed.). Pearson Prentice Hall: Upper Saddle River, New Jersey: Pearson Education International.

Heijs, W., van Deursen, A.-m., Leussink, M., \& Smeets, J. (2011). Re-searching the labyrinth of life-styles. Journal of Housing and the Built Environment, 26(4), 411-425. doi:10.1007/s10901-011-9237-6

Hendershott, P. H., Ong, R., Wood, G. A., \& Flatau, P. (2009). Marital history and home ownership: Evidence from Australia. Journal of Housing Economics, 18(1), 13-24. doi:10.1016/j.jhe.2008.09.002

Huang, H.-C. (2011). Factors Influencing Intention to Move into Senior Housing. Journal of Applied Gerontology, 31(4), 488-509. doi:10.1177/0733464810392225

Huang, Y., \& Clark, W. A. V. (2002). Housing Tenure Choice in Transitional Urban China: A Multilevel Analysis. Urban Studies, 39(1), 7-32. doi:10.1080/00420980220099041

Khozaei, F., Ayub, N., Hassan, A. S., \& Khozaei, Z. (2010). The Factors Predicting Students' Satisfaction with University Hostels, Case Study, Universiti Sains Malaysia. Asian Culture and History, 2(2), 148-158.

Kryger, T. (2009). Home ownership in Australia: data and trends: Parliamentary Library.

Kurz, K., \& Blossfeld, H. P. (2006). Home Ownership and Social Inequality in Comparative Perspective. Housing, Theory and Society, 23(4).

Kutty, N. K. (2005). A new measure of housing affordability: Estimates and analytical results. Housing Policy Debate, 16(1), 113-142.

Lauridsen, J., \& Skak, M. (2007). Determinants of homeownership in Denmark: Syddansk Universitet.

Manrique, J., \& Ojah, K. (2003). The demand for housing in Spain: an endogenous switching regression analysis. Applied Economics, 35(3), 323-336. doi:10.1080/00036840110111149

Mehdi, Y., Laily, H. P., Mumtazah, \& Turiman, S. (2009). Factors Affecting Family Economic status. European Journal of Scientific Research, 37(1), 94-109.

Mehta, A. C. (1997). Population Projections: Sub-National Dimensions. New Delhi: Commonwealth Publishers.

Ndubueze, O. J. (2009). Urban Housing Affordability and Housing Policy Dilemmas in Nigeria. (Doctor of Philosophy Unpublished Thesis), The University of Birmingham, Birmingham. 
Newton, P., \& Meyer, D. (2010). The Determinants of Urban Resource Consumption. Environment and Behavior, 44(1), 107-135. doi:10.1177/0013916510390494

NPC. (1991). National Population Commission Official Report of 1963 Population Census Figures. Retrieved from Abuja, Nigeria:

NPC. (2010). National Population Commission Official Report of 2006 Population Census Figures. Retrieved from Abuja, Nigeria:

Olayiwola, L. M., Adeleye, O., \& Ogunshakin, L. (2005). Public Housing Delivery In Nigeria: Problems And Challenges. Paper presented at the World congress on Housing Transforming Housing Environments through the Design, Pretoria South Africa.

Onu, V., \& Onu, A. J. C. (2012). Urban Residential Housing and Low-Income Earners: A Study of Makurdi Metropolis, Benue State, Nigeria. European Scientific Journal, 8(28), 231-246.

Quigley, J. M. (2007). Just Suppose: Housing Subsidies for Low Income Renters. Berkeley Program on Housing and Urban Policy.

Robinson, M., Scobie, G. M., \& Hallinan, B. (2006). Affordability of housing: concepts, measurement and evidence (06/04). Retrieved from New Zealand:

Song, S. (2000). Trends in Affordable Housing. Community Banker, 12, 36-39.

Tomori, M. A. (2007). Ibadan Metropolitan Area and The Challenges to Sustainable Development. Unpublished Monograpgh.

Toyin Sawyerr, P., \& Yusof, N. A. (2013). Student satisfaction with hostel facilities in Nigerian polytechnics. Journal of Facilities Management, 11(4), 306-322. doi:10.1108/jfm-08-2012-0041

Turner, T. M. (2003). Does investment risk affect the housing decisions of families? Economic Inquiry, 41(4), 675691.

UN-Habitat. (2011). United Nations Human Settlements Programme: Africa Affordable Land and Housing for a better urban future 2012. Retrieved from Nairobi, Kenya: UN-HABITAT web-site at http://www.unhabitat.org

Wang, W. (2010). The probability of Chinese mortgage loan default and credit scoring. Lincoln University. 